\title{
INTRODUCTION: GENERATION P IN THE TUNDRA. YOUNG PEOPLE AND THE RUSSIAN NORTH
}

\author{
Aimar Ventsel
}

This volume presents a selection of articles written by speakers at the conference "Generation P in the Tundra", which was held on 8-10 October 2004 at the Estonian Literary Museum in Tartu, Estonia. Scholars from Estonia, Russia, Germany, United Kingdom, Scotland, USA, and Austria presented papers beyond their usual topic of research or took particular interest in youth as a social group in different regions of Siberia.

About a year before, in 15-17 November 2003, a conference was held at the Max Planck Institute for Social Anthropology in Halle. The conference was held under the title "Everything is still before you': Being Young in Siberia Today", and was organised by Joachim Otto Habeck. This was the first Western academic conference dedicated to the Siberian youth. Both conferences demonstrated the diversity of the field labelled "young people in Siberia today". An argument that "youth is a growing topic within the Siberian studies" (Habeck 2004: 3) sounds cliché and has little validity, because this statement neglects the decades-long Soviet scholarship, the works of cultural planners, economists, and so forth. But youth as the topic of research within Siberian studies has been quite marginal indeed. Studies about Siberian natives leave the impression that the inhabitants of Siberia are either adult or older. The "ethnographic" Siberia is a male-dominated, highly spiritual (shamanism-driven) adult world. It seems as if Siberians are children who leap into adulthood, skipping the phase of youth. The truth is that youth have always been there. All Siberian natives have been young, they have had problems with their parents and peers, they have experienced first love, searched for identity, and struggled to become adult and take the responsibility, and have had all other moments that young people have in their lives. Why do we know so little about that?

There is quite a solid body of Western scholarship about Russian youth, and many topics of the post-Socialist period have been subject to study. The most 
popular topics seem to be music and music-related subcultures (Cushman 1995, Pilkington 1994, 1999), but also consumerism and new media (Omel'chenko \& Bliudina 2002), personhood and approaches to the future (Nafus 2006), and some works try to summarise all youth-related fields (Wallace \& Kovatcheva 1998). However, for the Western researchers en masse, the geography of Russian youth (and Eastern European in general) seems to stop at the Ural Mountains. In the history of Siberian ethnography, youth as a topic comes up in rare cases. Tsarist Russian and Soviet scholars hardly ever wrote about youth as a social group. Most subjects of their studies are adults: reindeer herders, hunters, fishers, men and women. Child care, toys and transmission of knowledge are mentioned, but those who are not adults are treated as a passive group who receive, are taken care of, and become important only after joining the ranks of adults. In fact, ethnic youth today is a heterogeneous group, the social position, cultural identity and life paths of whom vary from region to region, even from settlement to settlement. A part of youth is what outsiders understand as "traditional", which means living in the environment of hunting, fishing, or reindeer husbandry. But the other side of the coin is that native youth are loosely connected with the traditional economy and lifestyle. They study or work in the city or have settled down in villages and have no intention of leaving it for the taiga or tundra. There have been attempts to study these phenomena and most attention is paid to the topic in contemporary (Russian) Siberian studies. Many studies focus on indigenous youth in urban and rural context (Donskoi 2002, Lapparova 2002a,b, Malakhov 1995, Shcheikin et al. 2002). However, these studies are mainly from the field of sociology and regional studies: they give us a lot of quantitative data but provide little explanation for how to perceive youth as a group different from children and adults and derive from the Soviet sociological traditions which aim was simple - to study youth in order to "increase the effectiveness" of educating, controlling and forming the life paths of young people (e.g., Lebedev 1969). We still can argue that little is written about how the Siberian youth see themselves and how others see them. ${ }^{1}$

At the 2003 conference in Halle, Piers Vitebsky mentioned that Western scholars follow the footpaths of Soviet ethnographers (an aspect also mentioned in Gray et al. 2003), as they go to the tundra and the taiga and tend to ignore that Siberia is an industrial region where the level of urbanisation is extremely high. The history of the post-Second World War Siberia reveals that this was overwhelmingly a history of the young people. These were first of all young people from many parts of the former Soviet Union who came to Siberia to "conquer the wilderness". Young people, many of them proud members of Komsomol, the Young Communist League, were the driving force behind es- 
tablishing diamond and gold mines, building factories, constructing roads and cities. ${ }^{2}$ As in the past, the population of most Siberian cities, which now are also industrial centres, are very young. Even at a brief glance, a visitor of Siberian towns can see a lot of children, many playgrounds, and crowds of young people on the streets, sitting in bars, strolling in shopping centres, or visiting clubs. Much anthropological scholarship overlooks the fact that most regional centres of Siberia are also university towns, which means that they draw young people from rural and smaller urban settlements. Indeed, university students (studenty) are an important social, cultural and economic category for local inhabitants but not for researchers. Besides, there are other social age-related categories in Siberian towns and villages, like high school students (shkolniki), young adults who have graduated and hold jobs, and so forth. Modern Siberia does not exist in isolation and young people there are related to the global popular youth culture even to a greater degree than one expects. For example, various music-related subcultures have existed in Siberia already in the Soviet period. Moreover, Siberian cities gave rise to many important Soviet rock groups, which play a very important role in the development of the Soviet and post-Soviet youth culture (Troitskii 2007). Fashion and consumerism have always been important in Siberia. Due to the fact that in the Soviet period wages in Siberia were higher than in other parts of the Soviet Union, people were able to consume more. Mowatt (1970) repeatedly mentions in his book about his travels to Siberia that already in the 1960s youth were very visible in Siberia and were aware of the latest fashion trends. Despite Mowatt's being a highly unreliable source of critical information, this seems to hold true. Older people have told me that in the Soviet times they not only travelled to the big cities like Moscow, Leningrad, or Riga to satisfy their hunger for fashion clothes, music, and other commodities but these items were also brought to Siberia by black market dealers (fartsovshiki).

This diversity also symbolises the title of the conference in Tartu. Generation $P$ is a book by modern Russian author Viktor Pelevin (2000). It has been translated into German and English and several other major languages. While the book was advertised in trendy German media as a new cult book, in Russia it was burned at public squares alongside other works which were regarded as "too modern" and "harmful for the Russian youth". ${ }^{3}$ Generation $P$ by Pelevin stands for the generation of Pepsi Cola, a generation that grew up in the period of early market economy in post-Socialist Russia and tried to earn their living by unlawful means. One of the central themes in the novel is consumerism, or to be more precise, the hunger for consuming. In general terms, Generation $\mathrm{P}$ is a new generation, representing today's youth in the Russian Federation, the young people that do not avoid the "fruits" of the global (that is, 
Euro-American) mass culture and - if possible - are highly attracted to consumer culture. And even if some young people do not wish to be part of the consumer culture, it still reaches them through the media, youth magazines in the school library, small shops in the remote tundra and taiga villages that sell Pepsi, music tapes or CDs, and other commodities, fashionable clothes worn by their peers at school and so forth. There is nothing extraordinary in reindeer herders wearing reindeer fur clothes in the tundra and Europeanstyle clothes in the village. When returning from the tundra, they put on "city clothes" and go to a village disco in the local house of culture (or village club) at the weekend.

\section{SIBERIAN YOUTH IN THE GLOBAL CONTEXT}

During my stays in the Republic of Sakha in the Russian Far East, I noticed that for the local people youth is a meaningful and important category. ${ }^{4}$ In Yakutsk, the capital of the Republic of Sakha, there is a Department of Youth at the Ministry of Education that organises cultural events like concerts or sport games for the young people. Traders have discovered youth as a consumer group and have opened stores selling brand clothes like Reebok or MEXX. In the republic there exists a youth-oriented media with glossy magazines and special radio and TV shows. Last but not least, youth make themselves visible through violence, disturbance of public order and criminality. Judging from what I have heard and read about other regions of Siberia and the Russian North, this is a normal development. There is no reason to believe that young people are passive actors, without any impact or importance, are handed everything on a silver platter or as a result of decisions made by their parents. The articles published in this volume discuss Siberian and Northern-Russian youth in its diversity and demonstrate that youth in rural and urban context make decisions and are willing to take control over their lives. Some articles also discuss youth culture.

The volume shows that there are different aspects and layers in young people's lives which make the whole topic so fascinating. Authors who contribute to this volume discuss the history (Leete), the identity (Sántha, Hakkarainen), and the different sides of "tradition" (Wiget \& Balalaeva, Habeck, King, Sántha) among Siberian youth, popular culture and the youth's role in the state nation building process (Kuznetsov, Krist), to name a few.

Siberian studies are a subdiscipline which sometimes is at a loss with itself, remaining outside the central discussions of anthropology, and aspires to be more connected with (and contribute to) the general debates (see Gray et al. 
2003). A look at the issues discussed in this volume leads to the question: To which degree is the life of youth in Siberia and the Russian North comparable with the life of youth in Western Europe, Latin America, and Eastern Europe? How many similar processes are taking place in Siberia and Africa, in Asia, or in North America? Another question that we are faced with is what is specifically "Siberian" or "Russian" in our analysis?"

David Anderson (2004) has stated that the category of youth in Russia, and in Siberia, is different from Euro-American ones. He argues that young people in Russia are more "grown up" (to quote Habeck 2004: 6) than their age mates in the West, having a sense of responsibility toward their families, moreover having an "overwhelming desire to build families". Anderson (2004: 24) concludes that Russian youth in general are more collectivist than Euro-Americans who tend to be more individualistic in adapting themselves in the world of globalised market economy. Since the collapse of the Soviet Union, Russia has undergone a series of changes, but in general it means that there is a need (obligation, if you wish) to contribute to the family's wellbeing in order to receive support, if needed. Such reciprocal kin-based structures (that also include the economic participation of the young people) exist also in other developing countries. Golte and Adams (1987) have shown that family ties in Peruvian extended families reach different economic spheres and function as channels to move young people out of the village and help them to settle down in cities. When young people have established their position in the urban environment they help other family members to follow them (see, e.g., Golte \& Adams 1987). In some cases, the social networking can be a surprisingly conscious strategy for young people in the Third World (e.g., Anders 2005). The "sense of responsibility" for their own family (Anderson 2004, Habeck 2004) is a social norm and even young people from wealthy families follow this norm as shown in the case of Mexican bourgeoisie by Lomnitz and Pérez-Lizaur (1989). Of course, such attitudes and practices of both Russian and Latin-American youth differ from the generally individualist Euro-American social practices.

Being an active member of a family network is one aspect of the social life in Siberia today. Being socially conscious, being aware of one's responsibilities does not rule out the sides of life that are considered "youthful" in the traditional approach to cultural studies and anthropology. Music and fashion are a topic which is very prominent in the youth studies of nearly all continents and cultures. In a special programme of Andy Kershaw in BBC Radio 3 about music culture in Iran it was said that modern pop music, both local and imported, can be found even in very conservative environment as soon as there is any possibility of having it (Kershaw 2004). Music as a general worldwide means of rebellion is discussed in many works (Akindes 2002, Barrow \& Dalton 1997, 
Born 1993, Brusila 2002, Bryson 1996, Chye \& Kong 1996, Cushman 1995). At the same time, music and dance can be ways of transmitting moral norms, cultural ideas and creating (or supporting) ethnic identities (Hutnyk 2000, Wade 1999). Music is created everywhere in the world and more music is created as the means of producing and broadcasting it have become less costly. Music which is the manifestation of ethnic, social or racial identities often becomes a political issue (e.g., Toop 1992). Nikolay Kuznetsov's article in this volume shows that Komi pop music is a transmitter of the ethnic identity for Komi youth by means of showing that Komi culture can be modern and does not necessarily belong to the village sphere. Today, modern forms of music reach even the remotest regions and it is only natural that young people adapt these in their own culture. The fusion of imported music styles with local genres and creating own ethnic music is a process which started with the spread of recorded music (or even before). It has introduced a large variety of African, Latin-American or Asian music styles that either copy the imported genres or have created new ones (Ho 2007, Regev 2007). There is not only plenty of music around, but the music has also many functions. According to Kuznetsov, music is connected to the idea of preserving and using the language which reputation is decreasing. Komi music festivals have a political undertone, as was the case in Colombia (cf. Wade 1999) where music was a manifestation of social and racial identities and festivals were places to manifest and negotiate identities. The same processes are taking place, for example, in Sámi music in Scandinavia, where modern forms of pop music in the Sámi language have come to express the identity of a marginalised minority and their place in the modern world (Sámi exhibition in Estonian National Museum, Tartu, 2007).

Another issue is traditional music that can be performed in a "right" or a "wrong" way, and in this way it is linked to the discussion of identity. World music is a genre the importance of which - both as a form of expression and a platform to create identities and images - cannot be overstated. Various world music festivals like WOMAD (World of Music and Dance) also help to create the standards on which type of music should be considered "real" or "authentic" and what should not. In cultural studies, there is a discussion about the world music (e.g., Hutnyk 1998, Haynes 2005). However, the relationship of traditional music and the young people is not discussed here. Scholars focus on topics like authenticity and discuss (employing terms like 'hybridity', 'hegemony', 'domination', 'colonialism' and other key terms in cultural studies) the EuroAmerican audience's perception of the world music, the marketing of the exotic "other", or the cultural production in general. There is nothing wrong with the focus, but these discussions often tend to disregard the gender and age aspect. Here Alex King contributes to this field and introduces the catego- 
ries of age group and gender. In debates over cultural studies scholars often ignore the other side of the coin - that is, most of the music which is sold as the "world music" is made outside the Western world in indigenous communities and it is a cultural process, followed by local debates and group politics. Next to discussing issues like tradition and authenticity in Kamchatkan folk dance circles, King also analyses the very initial stage of creating world music and how young people are embedded into this process.

Identity is a major topic of research especially in cultural studies but also in anthropology. Identity has many sides, be it ethnic, social, racial, religious, cultural, or gender identity. Identity expresses itself in various situations; a very good example here is the British scholars who discuss the identities of Asian and Black youth in UK in terms of gender, race or social group (Alexander 2000, Dudrah 2002, Nesbitt 1998). Many of these studies deal with (secondor third-generation) migrant youth in urban environment. As mentioned, music is a highly popular subject in identity studies. Brah (1987), Dwyer (2000), Moddod (1990), and Raval (1989), for example, provide studies about gender, sports etc. without an overriding emphasis on music.

Identity is also an important topic in papers of this volume. Stuart Hall states, "We are confronted by a bewildering, fleeting multiplicity of possible identities, any one of which we could identify with" (Hall 1992: 277). This wide range of identities and the wide range of contexts where these identities appear spring up in many papers of this volume. King and Kuznetsov discuss indigenous youth identities in terms of making, performing and consuming music and dance. Stefan Krist shows how sports can be understood in terms of gender and ethnicity and how sports and identity are incorporated into the nation-building project of Buryatia. The Buryat Republic has turned Sukharban sports games into a cultural event which is accompanied by music performances, beauty pageants, and religious ceremonies. While sports, fashion, music, and the opposite sex are topics of interest frequently discussed among young people, in these sports games the young are faced with topics like race, ethnicity, and nation. A change of identity in the changing world is a global process and the Buryat Republic is not in a unique position when reconstructing "ancient" or "traditional" rituals to make them carriers of modern national identity. In Siberia, the same process of reconstructing identities is taking place in many regions like Tuva, Khakassia or Sakha. Thapar (1989) discusses the issue from the angle of Hindu nationalism; Dittmet and Kim 1993 tackle it in the context of China (on a discussion on festivals as community-building events, see Ryan 2006). Classical examples in this field can be found in the work by Hobsbawn and Ranger (1992), and also in the works by Anthony D. Smith (e.g., 2003). Krist's article points to the wide "range of identities" within 
the Surkharban games and discusses how many of them can the young people choose at the same time.

While Krist discusses the identity processes which have been initiated by the state policy and impacted by global symbols and media products, Elena Liarskaya's article deals with identity changes "from below". Of course, the Soviet state has caused shifts in the lifestyle and identity on the Yamal Peninsula through sedentarisation, urbanisation and educational politics, but Liarskaya demonstrates how the urban-rural/traditional-modern dichotomy that activists so often refer to is in reality a gradient of adaptation and movement within the indigenous community. In Arctic studies, the rather typical view is that the indigenous world imported into the European-style settlement and social environment, implicates a conflict between these two (Rasing 1994). This is probably true but the other side of the coin is that the Siberian indigenous people also are innovative and adaptive when in touch with the "outer world". The encounter of the indigenous world with the European world means first of all the adoption and use of new technologies (e.g., Adas 1996, Bird 1983).

Marina Hakkarainen and Florian Stammler introduce the subject of consumerism - another identity marker in youth studies. Hakkarainen discusses the symbiosis of the traditional religious and new esoteric practices in Markovo village, Chukotka. The flow of esoteric literature has reached every remote corner of Russia, and Siberia is no exception. The esoteric ideology that these books convey has become part of the 'self-representations' (a term derived by Hakkarainen) of a generation. Consumerism (or the anti-consumerist position) and its connection with identity is well covered in Western youth studies, starting with the classic work Common Culture by Willis, Jones, Canaan and Hurd (1990). Willis et al. show the creativity and variety of building up identities with the help of consumer goods (mainly clothes). Hebdige (1979) uses the term 'bricolage' to show how in different subcultures different, sometimes even contradictory symbols are used together to construct one's identity. According to Hakkarainen, in Markovo, where traditional religious knowledge and ideas coexist in one space with imported esoteric ideology, the cultural bricolage can exist due to mass media and trade. Stammler links consumption to many other topics like gender, age, communication, and the pragmatism of the Nenets on the Yamal Peninsula. Natives, even those who are seen as "very traditional", are as innovative as others. Anderson (2004, $2006 \& 2007)$ demonstrates that adapting new tools and materials by hunters does not mean a degradation of indigenous cultures, but that rather new tools, skills and materials are adapted in order to safeguard indigenous culture. 
Religion is another popular topic in social and cultural anthropology. Religion has been especially popular in Siberian studies, beginning with ethnography of the Tsarist and Soviet periods (which lasted from the end of the 19th century to 1991). From the perspective of anthropology religion is more often related to studies about identity, but some authors discuss religion also as an object per se, as a complex of symbols (e.g., Buzalka 2007, Day 2007, Pollack \& Olson 2007, Shoup 2008). Religion can also be part of the rebellion, as seen in the Mau Mau Uprising (Berman 1991, Lonsdale 1999). Two papers in this volume discuss religion as part of the life of young people, or, more precisely, young people as part of religion. Hakkarainen raises questions about culture and consumerism and discusses how in the Markovo village in Chukotka it is related with identity. The article broadly deals with the issue how young people search their own path and how they develop their perspective on the life around. This paper links very well to the series of studies that deal with the construction of identity by and the role of religion among the young people in different societies. As demonstrated by Vertovec and Rogers (1998), Smith (1999), and Damrell (1978), the social aspect of religion is important in developing the group identity of the young people. Hakkarainen shows how family ties (also family loyalties) and peer group relations affect religious preferences and the construction of young people's group identities. Moreover, her article shows that globalisation within the state - that is, the flow of ideologies and unexpected consumer goods - reaches every corner of its territory (e.g., Lemon 2008). Hakkarainen also shows that religion (as one of the markers of identity) enters into discussion with many other factors such as consuming and mass media, and the combination of all three with social networks is crucial for the identity-building of the Markovo youth.

Every young generation questions certain values of their parent culture. In youth studies the change of consuming habits is often discussed but so are the changes in social norms, media, or career strategies. Youth not only question values and norms of the previous generation, but the choices are often influenced by abrupt changes (like war) or more gradual (and less dramatic) changes in the economic, social, and political environment. Hakkarainen shows the discussion inside the Markovo community about the pros and cons of the new era and the ancestors' religious beliefs. When the problems surrounding religion are viewed in the wider context, it becomes obvious that this is a discussion about individual and family development (or changes in it). Refusing to follow traditional beliefs, a young person has to revise his/her attitude and adherence to social and cultural norms of the community. What Hakkarainen discusses is the very beginning of the process of radical changes in social norms 
and relations, and it has definitely something to do with the collapse of the Soviet Union, changes in economy, the emergence of a new consumer-oriented society, and, unfortunately, also with the falling apart of the old stable and habitual Soviet lifestyle.

Tatiana Bulgakova discusses Nanai shamanism as a changing practice and a flexible institution. Young Nanai appear to have found their way in the Socialist and post-Socialist environment, while remaining good citizens (though sometimes members of the Communist Party and state structures) and religious activists or shamans. There is a widely cultivated opinion that in the Soviet Union there existed a so-called official culture and an unofficial culture. I second to Yurchak (2006: 3, 6) who argues that emphasising this "binary approach" became very fashionable in the Perestroika era. Yurchak (2006) also criticises this black-and-white view and argues that the official and unofficial sphere existed together, and wherever necessary, overlapped. Shifting between the Soviet and the post-Soviet official structures and the Nanai religious world, young shamans are confronted with a phenomenon which is the same among many indigenous peoples all over the world: the difference between their culture and the dominant culture. This is often manifest in different views upon the law (Rasing 1994), or reciprocity and kinship (Bodenhorn 2000). Religion, as one of the most visible identity markers, has a very ambiguous position in this conflict. The Soviet Union has, reportedly, a long history of oppressing and forbidding various religious practices. Nevertheless, these practices have not been abandoned. ${ }^{6}$ Bulgakova's article not only relates with the debates about the nature of indigenous minority cultures but also with the multiple practices on many levels of the Soviet and post-Soviet society. Here it has to be reminded that young shamans, as discussed by Bulgakova, were also citizens of the state who, more or less successfully, lived official and unofficial lives. These lives coexisted in a single space and have formed a certain symbiosis.

Art Leete's article about the Kazym revolt, the Khanty resistance to the Soviet power in the 1930s and 1940s, leads one to think on the absence of the aspect of age in both contemporary Siberian studies and Siberian history. In the classic works by Forsyth (1992), Slezkine (1994), and Mote (1998), the involvement of different age groups in historical events is hardly noticeable. An attempt to restore the history of youth in the context of the Kazym rebellion is a valuable one. As Bloch (2004) has shown, the social environment of the youth, the specific historical situation and loyalty or opposition to the state structures affects the life paths, careers and values of people when in adult age. 


\section{TRADITION VERSUS MODERNITY}

In many aspects, 'tradition' is a popular cult term in Siberian studies. In Siberia, Russian, Soviet and Western scholars have largely studied - and continue to study - communities, and the many aspects of tradition that are perceived as 'traditional'. Tradition is also something that embodies the essence of indigenous cultures for many scholars, indigenous activists and intellectuals. Tradition stands for a whole set of elements, including language, economy, national costumes, technological skills, religious beliefs, certain moral values, and many more. According to such an approach, 'a loss of tradition' automatically means the extinction of indigenous groups. In Russia, reindeer husbandry, fishing and hunting are often officially named as 'traditional branches of economy' (traditsionnye otrasli ekonomiki). In 1996, many scholars and specialists were asked how they see the future of the Siberian indigenous peoples. Typically, 58 per cent of them argued that Siberian indigenous peoples can survive only when they remain involved with the 'traditional economies' and only one per cent conceded that indigenous groups could have a future in the urban industrial environment (Pika, Dahl \& Larsen 1996). This means that there are enough people - scholars and non-academics - who believe that Siberian indigenous peoples can exist only outside urban settlements, and the majority of them continue to live in the tundra or the taiga and follow the lifestyle of their ancestors. $^{7}$

In such discourse, modernity is seen as oppositional to tradition and in the context of the 'survival of indigenous cultures' it is seen as something negative, harmful, or degrading. Apparently, in popular approach 'modernity' is a set of qualities which include individualism, materialism, denial of the past, or disrespect towards parents. In terms of youth the aim of 'modernity' is to draw them away from their ancestors' lifestyle. Indigenous activists also appear to understand modernity as something unchangeable, very fixed on its qualities, like the invasion of mass culture, consumerism, loss of former values, etc. All over Siberia, there seem to be no variations in terms of speaking about 'negative modernity': complaints against it are very much the same, independent of the region. In this opposition between 'the good tradition' and 'the bad modernity' youth is especially under attack (e.g., Popov 1994). ${ }^{8}$ Because of the "unfavourable" influence of modernity, young people reject the old ways and turn to drugs, alcohol and smoking, and leave the tundra and taiga. There is little discussion among the indigenous activists and sympathetic scholars about other possible reasons for these processes, as television, shops, discos, or boarding schools all together alienate young people from 'the good tradition'. Neither is 
there any discussion about tradition and modernity representing the different sides of the same social environment. Is it possible that modernity could sometimes include some tradition? Or perhaps tradition sometimes incorporates a tiny part of modernity? No, theoretically the division between both concepts is strict and neverchanging.

One academic point of view on tradition is that tradition in the modern world is rather construed, and often invented to mobilise people around the elite (Hobsbawn \& Ranger 1992). Putnam (1993) links tradition directly to the functioning of power structures; and the Huntington's (1996) theory of different cultural zones that have their own 'cultural tradition' and compete with each other about the resources, is not much different. At the same time, works like those by Handler and Linneken (1984) question the polarity between traditional and modernity. Their comparison of the construction of identity and tradition in Quebec and Hawaii has shown that 'existing traditions' are a combination of the 'old' and 'new' symbols linked with the common sense of the people. This comparison shows, as do dozens of other studies, how the tradition that responds to specific needs of the present is being constructed and how the history is modelled to make it fit into the prevailing concept of nation. There are many excellent studies in the anthropological scholarship on nonEuropean indigenous groups that demonstrate how tradition is rendered into a tool for contesting or justifying claims to resources, especially land. Feit (1991) shows how sometimes even sympathetic scholars join the process to prove that tradition is very important in resource-claiming political processes. Tradition itself can sometimes have very contradictory content (see Shils 2006, Narayan 1997) but a central part in the lobbying of indigenous populations is for their rights to claim certain resources (Posey \& Dutfield 1996, Grenier 1998, Narayan 1997).

The discussion about tradition and modernity is different in the European setting. While in the non-European context tradition and modernity are at the different ends of the axis of good and bad, but can co-exist in the same time period, in the European discussion tradition and modernity are at the different ends of a linear historical development. Tradition is a thing of the past and European cultures have moved to the advanced state of modernity. The European vernacular view is that with the advent of modern times, tradition has been left behind. Here the concept of the "modern" is regarded as something universal and holistic. In the non-European indigenous setting scholars have showed that tradition is a very ambiguous and fluid concept, whereas in the European setting these qualities are attributed to modernity. Inglehart and Baker (2003: 179) argue that "cultural change seems to be path-dependent", 
meaning that some things from the past are being incorporated into the modern world. A fine example of the discussion about the "universal" qualities of modernity (and tradition) is the book Detraditionalization. Critical Reflections on Authority and Identity, edited by Paul Heelas, Scott Lash and Paul Morris (1996). This collection of essays about tradition, modernity and post-modernity, defends the idea of their coexistence. Although the authors of this volume discuss developments and changes (especially the development of the individual social and political freedom) in European culture, some arguments may be important also in the debates over non-European indigenous peoples. "Detraditionalization takes place alongside, or together with, tradition-maintenance," argues Heelas (et al. 1996: 2). Modern is not that modern and tradition is not that detraditionalised, because traditional societies are open to human agency (Heelas et al. 1996: 7-8). Authors of the volume (Luhmann, Thompson, Adam, and Beck \& Beck-Gernsheim) are sceptical about the struggle between tradition and modernity and believe that European individualism is the cultural product of a certain tradition. Zygmunt Baumann (1996) believes that even the individualist European societies need a sense of identity and moral which also means the maintenance of certain common-sense traditions. Niklas Luhmann adds that the "social system needs a memory" to "self-monitor himself" (1996: 50,60 ). Similarly to non-European societies, traditions can become linked with the economic activity in European societies (Luckmann 1996: 78). At the same time, traditions legitimise the practices of modern institutions (Thompson 1996: 92 ) as is the case with North-American natives or Siberian indigenous people fighting for their land rights. Altogether, tradition in European societies did not erode with the modernity (although some "reduction" of tradition took place there) but developed fields where tradition thrives (Luke 1996: 112-115). To survive, tradition must be "dynamic, contemporary and forward looking" (Heelas et al. 1996: 116), unless community building is difficult, if not impossible, even in the European states (Morris 1996).

In reality, there hardly exists a real gap between tradition and modernity in Siberia. All the articles published in this volume deal with tradition in one way or another. All of them demonstrate that in the Siberian setting, there is no ultramodern or consciously traditional youth. Of course, tradition and modernity can stand in conflict (as demonstrated by Hakkarainen) but at the same time the feature regarded as the most traditional of Siberian cultures - namely, shamanism - can be well adapted into the Soviet structures and exist alongside the Communist ideology. As Krist shows, the state itself may channel the coexistence of tradition and modernity. Buryat Surkharban sports games is a national event that emphasised, on the one hand, the historic legacy and her- 
itage of Buryatia, and on the other hand, the organisers used modern symbols and entertainment to attract people. Here the state itself combined tradition and modernity for political reasons. The policy of the Buryat state was no different from the legitimisation and mobilisation policy of the European states, which is discussed in Detraditionalization. Krist shows that the initiative to emphasise the tradition came from the state, from the top. To stress the indigenous heritage and historic legacy of the state by demonstrating the "ancient" folk culture at public events and turning indigenous feasts into national feasts is a common practice in Siberian regions like Tyva, Khakassia, Sakha or Buryatia with a prevailingly indigenous population. This means that the modern national (quasi-)state cultivates some portion of the (placative) tradition for the political ends.

In other articles of this volume, tradition is reflected in the practices and behaviour of the common people. The articles by King and Kuznetsov deal with tradition and modernity in music but from different angles. In King's discussion, Kamchatkan folklore groups have created their own conception of tradition, which some claim to be the only "right" or authentic tradition. This is quite common in Siberia, where cultural workers argue that their way to dance, sing, or make costumes is the most authentic, thus "more authentic" than that of other folklore collectives. More importantly, this traditional dance and music exists because it is supported by and incorporated into modern state structures. Such folklore groups usually belong to local houses of culture or regional departments of culture. Many leaders of such groups have been educated at the state institutions and are full members of the local state apparatus. The task of such cultural workers is to 'maintain' and 'develop' traditional culture and they represent the pinch of tradition that the state has incorporated via institutionalisation into the modernity. By employing a leader for a music group, the state also legitimises (and often gives the group monopoly over) their concept of the tradition. This folkloric tradition is run and managed by the categories of modern success and business. For example, the best folklore collectives travel around, often earn good money for performing at festivals abroad, and they highly value publicity and media coverage. This way the traditional music and dance is traditional only on the surface, but it is organised according to modern categories.

While the context of King's paper is how modernity incorporates tradition, Kuznetsov shows how tradition is modernised for the purpose of making it popular. The image of everything traditional in Siberia is that this is a rural, non-urban and "backward" culture. Kuznetsov shows how modernity is added to traditional music and this way the latter is rendered "progressive" and ac- 
ceptable for youth. There is a long and confusing discussion about the legitimacy of modern instruments, sounds, or techniques in the traditional music and the degree of authenticity in this music. Only this modern element helps traditional music to survive, overcome its negative reputation and find acceptance by the wider audience. In his discussions about Komi popular music, Kuznetsov raises the issue of the general backwardness of indigenous culture. It is not only Komi music but also the Komi language that suffers from being classified as too traditional and not modern enough.

The polarisation of backward v. progressive and its meaning is present also in the articles of István Sántha, Joachim Otto Habeck and Elena Liarskaya. Sántha and Habeck demonstrate which social consequences are perceived as "backward" and their popular connection to the non-urban, less comfortable and less well-off environment, whereas Liarskaya shows how the Nenets are bridging the gap between tradition and modernity by connecting two spheres (tundra and village) through social ties. All the three articles handle different combinations of tradition and modernity. While in Sántha's article people in the Western Buryat village are forced to become traditional due the decrease of modernity, Habeck discusses how traditional economy - reindeer herding becomes a resort for young higher education school dropouts. In these articles, tradition is viewed as a social fact, in which some people get involved. Many young people want to get away from the tradition, to follow the "lure of the city" as Habeck has called it. Liarskaya's article is quite different from the articles by Sántha and Habeck. The young Nenets who have been educated at boarding schools become the mediators between the modern and the traditional sphere. The traditional sphere of the Nenets largely benefits from its contacts with the modern "outer world", as is convincingly shown by Stammler.

The ways and degrees of how traditional and modernity are related to each other and affect each other are different and may exhibit individual differences even within a single family. Andrew Wiget and Olga Balalaeva analyse on the example of one family the impact of modern values on traditional lifestyle. The argument about the coexistence of tradition and modernity in one space is well illustrated by the biographies of two sisters who switch from traditional values to modern and back. The discussion about tradition and modernity should thus not be a discussion about the contesting and exclusive social and cultural spheres (as has often been suggested by indigenous activists) but about different constellations and about the dynamics that are causing these constellations to change. 


\section{VOLUME OUTLINE}

This special issue opens with two articles discussing the modern developments on the Yamal Peninsula, Northwest Siberia. Liarskaya discusses the position of the settlement Nenets as distinct, but not disconnected, from the Nenets life in the tundra within the indigenous community. The topic of sedentarisation and settlements in Siberian studies has been relatively one-sided. Settlements (villages, towns) are usually seen as something that destroys the native way of life, culture, identity, and so on. Liarskaya shows that this topic contains much more than just the story of assimilation or cultural degradation. The Yamal Nenets have incorporated settlements into their social space and make use of their existence. Young people switch back and forth between the tundra and settlement, possessing social skills and knowledge of both ways of life. Liarskaya demonstrates that Siberian indigenous cultures are flexible in their social strategies and that young people play an important role in this social flexibility.

Flexibility and adaptation is also the topic of Florian Stammler's article. He discusses the impact of the use of mobile phones upon the Nenets social life and economy. Paraphrasing the title of a book by Pelto (1987), who wrote about 'snowmobile revolution', Stammler calls this new process the 'mobile phone revolution'. Mobile phone is not only a communication tool, but has in the Yamal tundra radically changed some aspects of communication. News spreads faster over the tundra, but one purpose of visiting each other - namely, exchanging news - has disappeared. On the one hand, tundra camps no longer exist in relative isolation, but on the other hand, the element of surprise by sudden visits is lost. The article points out the different layers of the mobile phone use - age, gender, economic. At the same time, Stammler again demonstrates the flexibility of an indigenous culture which is capable of incorporating different new tools and patterns of communication without being in danger of annihilation.

Tatiana D. Bulgakova analyses the continuity in Nanai shamanic practices. Her main argument is that the Nanai religious practices are extremely flexible and have survived the various state policies of the Soviet period. According to the author, the Nanai shamanic tradition was largely transmitted by the people who were supposed to fight it, and were members of the Komsomol and the Soviet Union's Communist Party structures. Moreover, Bulgakova is convinced that the esoteric New Age shamanism today can be seen as the modification and continuation of the Nanai religious tradition. Bulgakova shows how shamanic practices have modernised and enlivened in the new situation in which the Nanai language is no longer used, even though it used to be impor- 
tant for the maintenance of the "traditional" Nanai religious practices. This paper provides a good insight into how Siberian religious practices have maintained their social and cultural importance and survived even the period of brutal Stalinist repressions between 1935 and 1953.

The article by Marina Hakkarainen forms a dialogue with Bulgakova's discussion. Hakkarainen suggests that under certain circumstances, new and old religious practices may stand in opposition, and discusses the conflict between the "imported" consumer-based and media-supported New Age beliefs with the local indigenous religion. In this struggle, young people have a highly ambiguous position because they are divided in two groups of adherents. Hakkarainen shows that the shift in religion in this Chukotkan village is linked to the shift in the economic and political environment. Religious preferences are also connected with the changes in or maintenance of social norms within the families.

Nikolay Kuznetsov's article deals with a topic which in cultural and social studies has been traditionally associated with youth - namely, music. Kuznetsov discusses the Komi modern music and its relation to ethnic processes. Modern pop music is often criticised by conservatives as transmitter of "alien" ideas, which have a negative impact on the youth. Kuznetsov demonstrates how the Komi media and modern culture, and especially music, function as mediators which can enhance the prestige of the Komi language in a situation when the younger generation of Komi regards it as something unprestigious and outdated, something that "belongs to village". The modern music and its being performed in public may improve the image of the Komi language (and other indigenous languages), increase its popularity and prestige.

Stefan Krist focuses not only on the music but also on the popular culture in Buryatia in general. On the example of Surkharban sports festival, which is organised by the state, Krist discusses the co-existence of the traditional folk music, dance, Buryat sports (kickboxing, breakdance), and various forms of pop music. He suggests that for the young people, these two spheres - traditional and modern - are not contradictory. At the Buryat festival, modern and traditional involves the interplay of ethnic and gender identities. Surkhaban is the festival that manifests traditional gender roles in Buryatia and, at the same time, gender in modern popular culture. Ethnicity becomes ambivalent in the event which is designed to construct the general national identity for the people of the republic. Since such major festivals are important for various Siberian non-Russian regions, this article addresses important topics which need to be further discussed in Siberian studies.

Alex D. King introduces folk dance groups in Kamchatka, East Siberia. The author compares different Koryak dance groups and shows how the individual 
strategies of 'cultural leaders' create competing perceptions of a tradition. In the situation where Siberian indigenous people take interest in marketing their culture for foreign tourists, discussion about the content and creation of the tradition has not had only academic but also practical significance.

The lack of the consumption possibilities - that is, low standard of living, general unemployment, and low (or non-existing) income - is the topic of István Sántha's article. The situation in a remote Evenki taiga village is typical for far too many Siberian villages. People in settlements with no hope for progress are mostly engaged in a subsistence economy; young people in general see no perspective for further personal development and have no reason to stay in the villages. Alcohol, like in many other isolated Siberian villages, is a main form of entertainment for the majority of the population, including also the young people. The village has a multi-ethnic population where "all the families sooner or later become Evenki" in the official record (p. 180). However, ethnic identity plays its role in the alcohol-fuelled conflicts where enmities, powered by the poor living conditions, are interpreted through the ethnic prism. This is a case study about the social complexity in a village where young people are faced with serious problems in search of a "brighter" future.

Joachim Otto Habeck continues this topic by comparing the life projects of the young people in the Republic of Komi and the Novosibirsk region. In his article, Habeck addresses issues like the city-village gradient, and the prestige of certain professions. He places the available choices and the decisions young people make into the wider context of economic stability which has become very visible in Russia since 2000. Habeck concludes that economic stability has resulted in an increase in free time, more money available for consumption, and a wider array of subcultures. However, Habeck also shows that young people have a very realistic worldview, and they are not fully relying on economic stability. In this article, the author also touches upon the meaning of the state policy in its attempt to create patriotic family-oriented ideology and how this policy affects the life choices of the youth.

Andrew Wiget and Olga Balalaeva address the agency and life choices in another Siberian region - namely, among the Khanty of West Siberia. This article, too, discusses the content and borders of tradition and modernity. Following the biographies of two Khanty sisters, the authors show that traditional norms and practices can be easily combined with modern (romantic and media-influenced) views on life, love, and marriage. Furthermore, the authors suggest that this combination is also linked with individual choices and understanding of what success is about. 
The last article in this volume is an attempt to reconstruct the social role in the historical past. Art Leete analyses the role of young people in the Khanty resistance movement in the Stalinist period. Here the question is how much agency did young people have in these events? The passivity or activity of youth is interpreted in the context of a Khanty uprising against the Soviet authorities. The youth and children were a direct cause of this uprising, known as the Kazym revolt; they were also participants in the events, and - last but not least - are also transmitters of the emotional significance and lore about this event.

\section{ACKNOWLEDGEMENTS}

My special gratitude goes to the Estonian Cultural Endowment for funding the conference and to Alex King and Joachim Otto Habeck for their useful comments which helped to improve this introduction. I am also deeply indepted to Mare Kõiva for specially editing the issue and to Kait Tamm and Maris Kuperjanov for their great commitment to making this issue happen.

\section{NOTES}

${ }^{1}$ An exception here is the continuous criticism of various (indigenous) activists about the lack of interest in their "culture" on the side of young people.

${ }^{2}$ Even though there are studies about the Gulag (The Chief Administration of Corrective Labor Camps and Colonies, a government agency in the Soviet Union which administered penal labor camps) which was a very important institution behind the industrialisation in the pre-Second World War Siberia and in the 1950s, the age and gender constellation of the Gulag has hardly been a matter of interest for scholars (e.g., Gregory \& Lazarev 2003). In any case, the Gulag was not targeted at youth, thus it may be agreed that the "Age of Youth" in Siberia began after the liquidation of the Gulag and increase in the importance of free wage labor.

${ }^{3}$ Interestingly, this act of Russian conservatives and ultranationalists did not receive particular attention in the Western media. In 1999 or 2000, parties like the Liberal Democratic Party of Russia called people in some Russian cities to give away books by certain authors (among these Pelevin's), compensated these with "acceptable" Russian books, and publicly burned the collected "harmful" books.

${ }^{4}$ Since 2000, I have conducted fieldwork in the Republic of Sakha and still visit the republic regularly almost every year.

5 This seems to represent a broader issue because there are voices which argue that categories like post-Socialism or transition countries are no longer relevant (Boyer 
\& Yurchak 2008, Gilbert et al. 2008). The beginning of this discussion introduces Russia as a research agenda in an entirely different context.

${ }^{6}$ Ironically, after Soviet state structures did everything to destroy Siberian indigenous religions, hundreds of folklorists and ethnographers invaded indigenous communities in search for indigenous religions to save these from extinction. Shamanism was probably the most favorite object of research in Soviet Siberian studies. Also, it was one of the most valued topics, as research into Shamanism was considered academically highly prestigious. Shamanism was often interpreted as the essence or the backbone of indigenous identity and cultures. However, not all scholars are able to say that they were in friendly terms with the indigenous shamans or had access to the ritual ceremonies.

7 The paradox of such ideology is that most of the staunchest supporters of this traditionalism live in cities (or at least in villages) and enjoy all the benefits of civilisation, like running water, TV soap operas, modern equipment, imported exotic food, possibilities to travel, regular and sufficient income and so on, cf. Ssorin-Chaikov 2003, Vladimirova 2006: 70-71, further on the indigenous 'national intelligentsia', see Gray 2005: 42.

8 This discussion is not something specific to Siberia or the indigenous minorities of the northern hemisphere. The same feelings exist in different parts of the world and in different spheres of human life. Eze (1997) discusses how the opposition of tradition v. scientific thinking in Africa is also linked with the opposition between communality v. individuality, social v. anti-social practices. The same oppositional pairs are also discussed in the context of the transmission of the tradition by Boyer (1990).

\section{REFERENCES}

Adam, Barbara 1996. Detraditionalization and Certainty of Uncertain Futures. In: P. Heelas, S. Lash \& P. Morris (eds.) Detraditionalization. Critical Reflections on Authority and Identity. Cambridge, MA \& Oxford: Blackwell, pp. 134-148.

Adas, Michael (ed.) 1996. Technology and European Overseas Enterprise: Diffusion, Adaption, and Adoption. (Expanding World: The European Impact on World History, 1450-1800), Vol. 7. Brookfield: Ashgate/Variorum.

Akindes, Simon 2002. Playing It "Loud and Straight". Reggae, Zouglou, Mapouka and Youth Insubordination in Côte d'Ivoire. In: M. Palmberg \& A. Kirkegaard (eds.) Playing with Identities in Contemporary Music in Africa. Uppsala: The Nordic Africa Institute, pp. 86-103.

Alexander, Claire E. 2000. The Asian Gang. Ethnicity, Identity, Masculinity. New York and Oxford: Berg Publishers.

Anders, Gerhard 2005. Civil Servants in Malawi: Cultural Dualism, Moonlighting and Corruption in the Shadow of Good Governance. $\mathrm{PHD}$ thesis. Rotterdam: Erasmus University.

Anderson, David G. 2004. 'Everything is Still before You': The Irony of Youth Discourse in Siberia. Sibirica. Vol. 4, No. 1, pp. 14-30. 
Anderson, David G. 2006. Dwellings, Storage and Summer Site Structures among Siberian Orochen Evenkis: Hunter-Gatherer Vernacular Architecture under PostSocialist Conditions. Norwegian Archaeological Review. Vol. 39, No. 1, pp. 1-26. Anderson, D. 2007. Mobile Architecture and Social Life: The Case of the Conical Skin Lodge in the Putoran Plateau Region. In: S. Beyries \& V.Vaté (eds.) Les Civilisations du renne d'hier et d'aujourd'hui. Approches ethnohistoriques, archéologiques et anthropologiques. Antibes: Editions APDCA, pp. 43-64.

Barrow, Steve \& Dalton, Peter 1997. Reggae. The Rough Guide. The Definitive Guide to Jamaican Music, from Ska through Roots to Ragga. London, New York: Penguin Books.

Baumann, Zygmunt 1996. Morality in the Age of Contingency. In: P. Heelas, S. Lash \& P. Morris (eds.) Detraditionalization. Critical Reflections on Authority and Identity. Cambridge, MA; Oxford: Blackwell, pp. 49-58.

Beck, Ulrich \& Beck-Gernsheim, Elizabeth 1996. Individualisation and 'Precarious Freedoms': Perspectives and Controversies of a Subject-Orientated Sociology. In: P. Heelas, S. Lash \& P. Morris (eds.) Detraditionalization. Critical Reflections on Authority and Identity. Cambridge, MA \& Oxford: Blackwell Publishers, pp. $23-48$.

Berman, Bruce J. 1991. Nationalism, Ethnicity, and Modernity: The Paradox of Mau Mau. Canadian Journal of African Studies / Revue Canadienne des Études Africaines. Vol. 25, No. 2, pp. 181-206.

Bird, Nurit 1983. Wage-Gathering: Socio-Economic Changes and the Case of the FoodGatherer Naikens of South India. In: P. Robb (ed.) Rural South Asia. Linkages, Change and Development. London: Curzon Press, pp. 75-87.

Bloch, Alexia 2004. Red Ties and Residential Schools. Indigenous Siberians in a PostSoviet State. Philadelphia: University of Pennsylvania Press.

Bodenhorn, Barbara 2000. "It's Good to Know Who Your Relatives Are but We Were Taught to Share with Everybody": Shares and Sharing among Inupiaq Households. In: G.W. Wenzel, G. Hovelsrud-Broda \& N. Kishigami (eds.) The Social Economy of Sharing: Resource Allocation and Modern Hunter-Gatherers. Papers Presented at the Eighth Conference on Hunting and Gathering Societies (CHAGS 8), Senri Ethnological Studies No. 53, Osaka: National Museum of Ethnology, pp. 27-60.

Born, Georgina 1993. Afterword: Music Policy, Aesthetic and Social Difference. In: T. Bennett, S. Frith, L. Grossberg, J. Shepherd \& G. Turner (eds.) Rock and Popular Music. Politics, Policies, Institutions. London \& New York: Routledge, pp. 266-292.

Boyer, Dominic \& Yurchak, Alexei 2008. Postsocialist Studies, Cultures of Parody and American Stiob. Anthropology News (November 2008), pp. 9-10.

Boyer, Pascal 1990. Tradition as Truth and Communication: A Cognitive Description of Traditional Discourse (Cambridge Studies in Social and Cultural Anthropology). Cambridge: Cambridge University Press.

Brah, Avtah 1987. Women of South Asian Origin in Britain: Issues and Concerns. South Asia Research. Vol. 7, No. 1, pp. 39-54. 
Brusila, Johannes 2002. "Modern Traditional” Music from Zimbabwe. Virginia Mukwesha's Mbira Record "Matare". In: M. Palmberg \& A. Kirkegaard (eds.) Playing with Identities in Contemporary Music in Africa. Uppsala: The Nordic Africa Institute, pp. 35-45.

Bryson, Bethany 1996. "Anything But Heavy Metal”: Symbolic Exclusion and Musical Dislikes. American Sociological Review. Vol. 61, No. 5, pp. 884-899.

Buzalka, Juraj 2007. Nation and Religion: The Politics of Commemoration in SouthEast Poland. Berlin: LIT.

Chye, Phua S. \& Kong, Lily 1996. Ideology, Social Commentary and Resistance in Popular Music: A Case Study of Singapore. Journal of Popular Culture. Vol. 30, No. 1 (summer), pp. 215-231.

Cushman, Thomas 1995. Notes from Underground. Rock Music Counterculture in Russia. Albany: State University of New York Press.

Damrell, Joseph 1978. Search for Identity: Youth, Religion, and Culture. Sage Library of Social Research. Beverly Hills, CA: Sage Publications.

Day, Abby (ed.) 2007. Religion and the Individual: Belief, Practice, Identity. Aldershot, Hampshire \& Burlington, VT: Ashgate Publishing.

Dittmer, Lowell \& Kim, Samuel S. (eds.) 1993. China's Quest for National Identity. New York: Cornell University Press.

Donskoi, Feodosii S. 2002. Sotsial'no-ekonomicheskie problemy vozrozhdeniia i razvitiia dukhovnoi kul'tury korennykh malochislennykh narodov Severa, Sibiri i dal'nego Vostoka. [Socio-Economical Problems in the Revival and Progress of the Spiritual Culture of the Small Peoples of the North, Siberia and the Far East.] In: I. I. Sheikin, I.F. Lapparova, A.I. Savvinov, V.A. Petrova, M.P. Lukina \& N.D. Petrova (eds.) Dukhovnaia kul'tura narodov Severa i Arktiki v nachale tret'ego tysiacheletiia. Tezisy vserossiiskoi konferentsii s 19 po 24 avgusta 2002 goda. Yakutsk: Severoved, pp. 16-21.

Dudrah, Rajinder K. 2002. Drum'n'dhol: British Bhangra Music and Diasporic South Asian Identity Formation. European Journal of Cultural Studies. Vol. 5, No. 3, pp. 363-383.

Dwyer, Claire 2000. Negotiating Diasporic Identities. Young British South Asian Muslim Women. Women's Studies International Forum. Vol. 23, No. 4, pp. 475-486.

Eze, Emmanuel C. (ed.) 1997. African Philosophy: An Anthology. Malden: Blackwell Publishers.

Feit, Harvey A. 1991. The Construction of Algonquian Hunting Territories. Private Property as Moral Lesson, Policy Advocacy, and Ethnographic Error. In: G.W.J. Stocking (ed.) Colonial Situation. Essays on the Contextualization of Ethnographic Knowledge. London: History of Anthropology. Vol. 7, pp. 109-114.

Forsyth, James 1992. A History of the Peoples of Siberia. Russia's North Asian Colony 1581-1990. Cambridge: Cambridge University Press.

Gilbert, Andrew; Greenberg, Jessica; Helms, Elissa \& Jansen, Stef 2008. Reconsidering Postsocialism from the Margins of Europe. Anthropology News (November 2008), pp. 10-11.

Golte, Jürgen \& Adams, Norma 1987. Los Caballos de Troya de los invasores: estrategias campesinas en la conquista de la Gran Lima. Lima: Instituto de Estudios Peruanos. 
Gray, Patty A. 2005. The Predicament of Chukotka's Indigenous Movement. Post-Soviet Activism in the Russian Far North. Cambridge: Cambridge University Press.

Gray, Patty A.; Vakhtin, Nikolai \& Schweitzer, Peter 2003. Who Owns Siberian Ethnography? A Critical Assessment of a Re-Internationalized Field? Sibirica. Vol. 3, No. 2, pp. 194-216.

Gregory, Paul R. \& Lazarev, Valery (eds.) 2003. The Economics of Forced Labor. The Soviet Gulag. Stanford, California: Hoover Institution Press.

Grenier, Louise 1998. Working with Indigenous Knowledge: A Guide for Researchers. Ottawa: IDRC. Available online at http://www.idrc.ca/openebooks/847-3/, last accessed in February 2009.

Habeck, Joachim O. 2004. Introduction: Growing Research on Youth in Siberia. Sibirica. Vol. 4, No. 1, pp. 2-13.

Hall, Stuart 1992. The Question of Cultural Identity. In: S. Hall, D. Held \& T. McGrew (eds.). Modernity and its Futures. Cambridge UK: The Open University, pp. 274 316

Handler, Richard \& Linnekin, Jocelyn 1984. Tradition, Genuine or Spurious. The Journal of American Folklore. Vol. 97 (No. 385 Jul-Sept), pp. 273-290.

Haynes, Jo 2005. World Music and the Search for Difference. Ethnicities.Vol. 5, No. 3, pp. 365-385.

Hebdige, Dick 1979. Subculture: The Meaning of Style. New York: Methuen.

Heelas, Paul 1996. Introduction: Detraditionalization and its Rivals. In: P. Heelas, S. Lash \& P. Morris (eds.) Detraditionalization. Critical Reflections on Authority and Identity. Cambridge, MA \& Oxford: Blackwell Publishers, pp. 1-20.

Heelas, Paul; Lash, Scott \& Morris, Paul (eds.) 1996. Detraditionalization. Critical Reflections on Authority and Identity. Cambridge, MA \& Oxford: Blackwell Publishers.

Ho, Wai-Chung 2007. Music and Cultural Politics in Taiwan. International Journal of Cultural Studies. Vol. 10, No. 4, pp. 463-483.

Hobsbawm, Eric J. \& Ranger, Terence O. (eds.) 1992. The Invention of Tradition. Cambridge: Cambridge University Press.

Huntington, Samuel P. 1996. The Clash of Civilizations and the Remaking of World Order. New York: Simon \& Schuster.

Hutnyk, John 1998. Adorno at Womad: South Asian Crossovers and the Limits of Hybridity-Talk. Postcolonial Studies. Vol. 1, No. 3, pp. 401-426.

Hutnyk, John 2000. Critique of Exotica: Music, Politics, and the Culture Industry. London: Pluto Press.

Inglehart, Ronald \& Baker, Wayne E. 2003. Modernization, Cultural Change, and the Persistence of Traditional Values. In: R. A. Dahl, I. Shapiro, \& J. A. Cheibub (eds.) The Democracy Sourcebook. Cambridge, MA: MIT Press.

Kershaw, Andy 2004. Kershaw in Iran 2004. On-location audio features. Radio programme for BBC Radio 3. Available at http://www.bbc.co.uk/radio3/worldmusic/ onlocation/iran2004.shtml, last accessed in February 2009.

Lapparova, Irina F. 2002a. Sotsial'naia adaptatsiia korennykh malochislennykh narodov Severa v usloviakh intensivnogo promyshlennogo osvoeniia Yakutii. [The Social Adaptation of the Small Peoples of the North in the Situation of Active Advances in Industrialization in Yakutia.] Tezisy vserossiiskoi konferentsii 
"Dukhovnaia kul'tura narodov Severea i Arktiki v nachale tret'ego tysiacheletiia". Yakutsk: Severoved, pp. 29-30.

Lapparova, Irina F. 2002b. Sotsial'nye posletsviia promyshlennogo osvoeniia Yakutii v raionakh prozhivaniia korennykh malochislennykh narodov Severa. [The Social Consequences of Advances in Industrialization in the Residential Regions of the Small Peoples of the North in Yakutia.] In: G. A. Ivanov et al. (eds.) Malochislennye etnosy Severa Respubliki Sakha (Yakutiia) glazami molodykh uchenykh. Yakutsk: RAN SO IPMNS, pp. 15-20.

Lebedev, Sergei N. 1969. Youth in Soviet Society. Youth \& Society. Vol. 1, No. 2, pp. 179 197.

Lemon, Alaina 2008. Writing against the New "Cold War". Anthropology News (November 2008), pp. 11-12.

Lomnitz, Larissa A. \& Pérez-Lizaur, Marisol 1989. The Origins of the Mexican Bourgeoisie: Networks as Social Capital. In: T. Schweitzer (ed.) Netzwerkanalyse. Ethnologische Perspektiven. Berlin: Dietrich Reimer Verlag, pp. 35-46.

Lonsdale, John 1999. Kikuyu Christianities. Journal of Religion in Africa. Vol. 29, No. 2, pp. 206-229.

Luckmann, Thomas 1996. The Privatization of Religion and Morality. In: P. Heelas, S. Lash \& P. Morris (eds.) Detraditionalization. Critical Reflections on Authority and Identity. Cambridge, MA \& Oxford: Blackwell Publishers, pp. 72-86.

Luhmann, Niklas 1996. Complexity, Structural Contingencies and Value Conflicts. In: P. Heelas, S. Lash \& P. Morris (eds.) Detraditionalization. Critical Reflections on Authority and Identity. Cambridge, MA \& Oxford: Blackwell, pp. 59-71.

Malakhov, Sergei 1995. Bezrabotnye Iugry: sotsial'nyi portret. [Unemployed Ugrans: A Social Portrait.] Surgut: Severnyi dom.

Moddod, Tariq 1990. British Asian and Muslims and the Rushdie Affair. The Political Quarterly. Vol. 61, No. 2, pp. 143-160.

Morris, Paul 1996. Community Beyond Tradition. In: P. Heelas, S. Lash \& P. Morris (eds.) Detraditionalization. Critical Reflections on Authority and Identity. Cambridge, MA \& Oxford: Blackwell Publishers, pp. 223-249.

Mote, Victor L. 1998. Siberia. Worlds Apart. Boulder \& Oxford: Westview Press, Perseus Books Group.

Mowat, Farley 1970. The Siberians. London: Heinemann.

Nafus, Dawn 2006. Post-Socialism and Notions of Context in St Petersburg. The Journal of the Royal Anthropological Institute. Vol. 12, No. 3, September, pp. 607-624.

Narayan, Uma 1997. Dislocating Cultures. London \& New York: Routledge.

Nesbitt, Eleanor 1998. British, Asian and Hindu: Identity, Self-narration and the Ethnographic Interview. Journal of Beliefs \& Values. Vol. 19, No. 2, pp. 189-200.

Omel'chenko, Elena \& Bliudina, Ul'iana 2002. On the Outside Looking In? The Place of Youth in Russia's New Media and Information Space. In: H. Pilkington, E. Omel'chenko, M. Flynn, U. Bliudina \& E. Starkova (eds.) Looking West? Cultural Globalization and Russian Youth Cultures. University Park, Pennsylvania: The Pennsylvania State University Press, pp. 21-49.

Pelevin, Viktor 2000. Generation "P”. Moscow: Vargus. 
Pelto, Pertti J. 1987. The Snowmobile Revolution. Technology and Social Change in the Arctic. Prospect Heights, Illinois: Waveland Press.

Pika, Alexander; Dahl, Jens \& Larsen, Inge (eds.) 1996. Anxious North. IWGIA Document No. 81. Copenhagen: IWGIA.

Pilkington, Hilary 1994. Russia's Youth and Its Culture. A Nation's Constructors and Constructed. London \& New York: Routledge.

Pilkington, Hilary 1999. Reconfiguring "the West”. In: H. Pilkington, E. Omel'chenko, M. Flynn, U. Bliudina \& E. Starkova (eds.) Looking West? Cultural Globalization and Russian Youth Cultures. University Park, Pennsylvania: The Pennsylvania State University Press, pp. 165-200.

Pollack, Detlef \& Olson, Daniel V. A. (eds.) 2007. The Role of Religion in Modern Societies. New York: Routledge.

Popov, Boris N. 1994. Izmenenie sem'i narodov Yakutii. [Changes in Family among the People of Yakutia.] Yakutsk: Ministerstvo obrazovaniia respubliki Sakha (Yakutia).

Posey, Darrel A. \& Dutfield, Graham 1996. Beyond Intellectual Property: Toward Traditional Resource Rights for Indigenous Peoples and Local Communities. Ottawa: International Development Research Centre.

Putnam, Robert D. 1993. Making Democracy Work: Civic Traditions in Modern Italy. Princeton, NJ: Princeton University Press.

Rasing, Wilhelmus C. E. 1994. "Too Many People": Order and Nonconformity in Iglulingmiut Social Process. Nijmegen: Katholieke Universiteit, Faculteit der Rechtsgeleerdheid.

Raval, Sadhna 1989. Gender, Leisure and Sport: A Case Study of Young People of South Asian Descent - A Response. Leisure Studies. Vol. 8, No. 3 (September), pp. 237-240.

Regev, Motti 2007. Ethno-National Pop-Rock Music: Aesthetic Cosmopolitanism Made from Within. Cultural Sociology. Vol. 1, No. 3, pp. 317-341.

Ryan, John S. 2006. The Range - and Purposes - of Australian Public Festivals That are Functioning at Present. Folklore: Electronic Journal of Folklore. Vol. 34, pp. 7-30.

Shcheikin, I. I., Lapparova, I. F., Savvinov, A. I., Petrova, V. A., Lukina, M. P., and Petrova, N. D. 2002. Tezisy vserossiiskoi konferentsii "Dukhovnaia kul'tura narodov Severa i Arktiki v nachale tret'ego tysiacheletiia". [Abstracts of All-Russian Conference "Spiritual Culture of the Peoples of the North and Arctic Region at the Beginning of the Third Millennium".] Yakutsk: RAN SO IP MNS.

Shils, Edward A. 2006. Tradition. Chicago: The University of Chicago Press.

Shoup, Brian 2008. Conflict and Cooperation in Multi-Ethnic States: Institutional Incentives, Myths, and Counter-Balancing. London \& New York: Routledge.

Slezkine, Yuri 1994. Arctic Mirrors. Russia and the Small Peoples of the North. Ithaca, New York: Cornell University Press.

Smith, Anthony D. 2003. Chosen Peoples: Sacred Sources of National Identity. Oxford: Oxford University Press.

Smith, Elizabeth S. 1999. The Effects of Investments in the Social Capital of Youth on Political and Civic Behavior in Young Adulthood: A Longitudinal Analysis. Political Psychology. Vol. 20, No. 3, pp. 553-580. 
Ssorin-Chaikov, Nikolai 2003. The Social Life of the State in Subarctic Siberia. Stanford, CA: Stanford University Press.

Thapar, Romila 1989. Imagined Religious Communities? Ancient History and the Modern Search for a Hindu Identity. Modern Asian Studies. Vol. 23, No. 2, pp. 209-231.

Thompson, John B. 1996. Traditional and Self in a Mediated World. In: P. Heelas, S. Lash \& P. Morris (eds.) Detraditionalization. Critical Reflections on Authority and Identity. Cambridge, MA \& Oxford: Blackwell, pp. 89-108.

Toop, David 1992. Rap Attack. African Jive bis Global Hiphop. München: Wilhelm Heyne Verlag.

Troitskii, Artemi 2007. Back in the USSR. Sankt-Peterburg: Amfora.

Vertovec, Steven \& Rogers, Alisdair 1998. Muslim European Youth: Reproducing Ethnicity, Religion, Culture. Research in Ethnic Relations Series. Aldershot:Ashgate.

Vladimirova, Vladislava 2006. Just Labor: Labor Ethic in a Post-Soviet Reindeer Herding Community. Uppsala: University of Uppsala.

Wade, Peter 1999. Working Culture. Making Cultural Identities in Cali, Columbia. Current Anthropology. Vol. 40, No. 4, pp. 449-470.

Wallace, Claire \& Kovatcheva, Sijka 1998. Youth in Society. The Construction and Deconstruction of Youth in East and West Europe. London: Palgrave Macmillan.

Willis, Paul E. with Jones, Simon; Canaan, Joice \& Hurd, Geoffrey 1990. Common Culture. Milton Keynes: Open University Press.

Yurchak, Alexei 2006. Everything Was Forever, Until It Was No More: The Last Soviet Generation. Princeton \& Oxford: Princeton University Press. 